\title{
Performance effects of analytics capability, disruption orientation, and resilience in the supply chain under environmental uncertainty
}

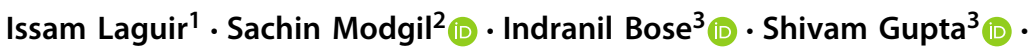 \\ Rebecca Stekelorum ${ }^{4}$
}

Accepted: 6 December 2021

(c) The Author(s), under exclusive licence to Springer Science+Business Media, LLC, part of Springer Nature 2021

\begin{abstract}
The relationship between Analytics Capability of an Organization (ACO) and both Supply Chain Disruption Orientation (SCDO) and Supply Chain Resilience (SCR) in order to achieve adequate operational performance in an era of environmental uncertainty is carried out in this study. Total three hypotheses (seven sub-hypotheses) using a survey of 405 respondents are collected via a pre-tested instrument and tested further. Results indicated the influence of ACO on both SCDO and SCR to achieve the desired degree of operational performance. However, under the moderation of environmental uncertainty, the link between ACO and SCDO was not supported, although the link between ACO and SCR was supported and this further enhanced operational performance. Further investigation of unsupported hypotheses using statistical analysis was conducted to gain deeper insights. It is explained how ACO impacted dynamic capabilities to influence operational performance. The contribution to theory of this study lies in explaining the role of dynamic capabilities that emerge from analytics as compared to the traditional view of supply chain classification. Further, the influence of environmental
\end{abstract}

Indranil Bose

indranil.bose@neoma-bs.fr

Issam Laguir

i.laguir@montpellier-bs.com

Sachin Modgil

sach.modgil@gmail.com

Shivam Gupta

shivam.gupta@neoma-bs.fr

Rebecca Stekelorum

rebecca.stekelorum@icn-artem.com

1 Department of Finance, Control and Law, Montpellier Business School, 2300 Avenue des Moulins, 34185 Montpellier, France

2 Department of Operations Management, International Management Institute Kolkata, 2/4 C, Judges Ct Rd, Alipore, Kolkata, West Bengal 700027, India

3 Department of Information Systems, Supply Chain Management \& Decision Support, NEOMA Business School, 59 Rue Pierre Taittinger, 51100 Reims, France

4 Department of Strategy and Entrepreneurship, ICN Business School, CEREFIGE, 54000 Nancy, France 
uncertainty on positioning dynamic capabilities strategically to address disruption in supply chains is discussed in the present study.

Keywords Analytics capability of organization - Dynamic capability view · Environmental uncertainty $\cdot$ Supply chain disruption orientation $\cdot$ Supply chain resilience

\section{Introduction}

In today's ambiguous business environment, organizations need to be particularly attentive to achieve the desired operational performance. Environmental uncertainty arises from the changing landscape of competition, consumer preferences, globalization and increased focus on innovation (Syed et al., 2020; Yayla \& Hu, 2012). Companies respond to this environmental uncertainty by adopting a variety of approaches and orientations to ensure their competitiveness and the desired level of operational performance (Liu et al., 2019; McLaren et al., 2011; Teo \& Pian, 2003). However, a disruption in the supply chain can bring the best plans to a halt, profoundly affecting business continuity (Baghersad \& Zobel, 2021; Xu et al., 2016). Disruptions in the supply chain hamper the efficiency of operations by impacting quality, cost, processing, sourcing and delivery of products and services (Chopra \& Sodhi, 2014; Downes \& Nunes, 2013; Pereira, 2009; Tomlin, 2006; Tönnissen \& Teuteberg, 2020; Xue et al., 2018). The disruptions may be due to events like pandemics, cyber-attacks, natural disasters or product and service problems (Min, 2019; Nguyen \& Nof, 2019). The recent Covid-19 outbreak disrupted many supply chains, although some were able to return to normal quickly (Ivanov, 2020a, b). Other notable disruptions to supply chains in the past include Hurricane Katrina in 2005 and the SARS outbreak in 2003, but history attests to many other unanticipated disruptions, such as factory fires and political upheavals (Li et al., 2013; SimchiLevi et al., 2014). Today's supply chains need to be structurally strong enough to sense the arrival of undesirable events and be ready with agile, adaptable and alignment capabilities (Lee, 2004). For instance, Dell responded better than Apple in 1999 when an earthquake in Taiwan disrupted the supply chain for memory chips (Chopra \& Sodhi, 2004; Sheffi \& Rice., 2005). It is thus crucial for companies to build an appropriate amount of resilience in their supply chains. Both Supply Chain Disruption Orientation (SCDO) and Supply Chain Resilience (SCR) can positively impact an organization's performance planning (Bode et al., 2011; Konovalenko \& Ludwig, 2019; Patel et al., 2013). Top management therefore needs to consider these factors to minimize supply chains risks (Chopra \& Sodhi, 2014; Villena et al., 2018). Yet it has been hard to quantify risk in supply chains using traditional models.

Over the last two decades, however, supply chains have started using data more intensively to design their strategies and companies are adopting analytics for this (Chen et al., 2015; LaValle et al., 2011; Shao et al., 2018). The analytics capabilities of organizations (ACO) can facilitate the development of better authenticated and validated insights to transform their supply chains (Liu et al., 2020). The ambidextrous organizations are better equipped with ACO. "Organizational ambidexterity refers to the ability of an organization to both explore and exploit-to compete in mature technologies and markets where efficiency, control, and incremental improvement are prized and to also compete in new technologies and markets where flexibility, autonomy, and experimentation are needed" (O'Reilly \& Tushman, 2013). ACO affects supply chain ambidexterity and rapidity, which then impact firm performance. The literature has shown the usefulness of the Resource Based View (RBV) and the Dynamic Capabilities View (DCV) to orient resources and enhance capabilities to achieve competitive 
gains (Chae et al., 2014; Dubey et al., 2020; Shibin et al., 2020). DCV facilitates organizational alignment so that big data can be leveraged in a systematic manner (Agarwal \& Dhar, 2014; Chen et al., 2015; Ghasemaghaei et al., 2017). The capability to handle different types of data encourages companies to opt for analytic applications in their supply chains (Seddon $\&$ Currie, 2017). ACO help companies develop unique capabilities for detecting quality problems, clustering customers, understanding their requirements, and setting the right price and margin for products (Grover et al., 2018; LaValle et al., 2011; Sheffi \& Rice., 2005). It further enhances the information processing capabilities that capture, integrate and analyse the big data that drives business value (Saggi \& Jain, 2018). Thus, analytics improves a firm's competitive intelligence capabilities in terms of infrastructure, assessment, and application to different business scenarios (Chen et al., 2012; Gupta \& George, 2016). Companies can use analytics to design their strategic orientation and impact performance (Grover et al., 2018).

Apart from developing data-driven capabilities, companies need to take appropriate actions to deploy insights and critically scan for stakeholders' inactive participation in providing business value (Côrte-Real et al., 2017). Inactive participation may be psychological, sociotechnical, economic, socio-cognitive or political in nature (Barnett \& Pontikes, 2008; Kwon et al., 2014), and this inertia can impact multiple stages of the analytics cycle. Companies also need to look at the external factors that may be barriers to turning analytics into a dynamic capability (Shorfuzzaman et al., 2019; Sun et al., 2018). In highly turbulent and dynamic environments, the insights derived from analytics can influence SCR and hence operational performance (Chen et al., 2015; Tiwari et al., 2018).

Today's supply chains are time-sensitive and disruptions heavily impact their operational performance. It is therefore important that companies develop their own style of awareness, consciousness and recognition capabilities, which often emerge from the experience of dealing with disruptive events (Ambulkar et al., 2015). These events help form the firm's orientation toward future supply chain disruptions (Patel et al., 2013). In fact, greater SCDO is found to be associated with bigger buffers and an appetite for risk (Bode et al., 2011). In addition to SCDO, scholars have found that SCR is also an effective means to attain desired operational performance (Min et al., 2019; Ortas et al., 2014). SCR enables a firm to return to its original state or move to a new but stable state. It helps maintain visibility, flexibility, responsiveness and collaboration in operations during uncertain times. SCR is also a capability for achieving and sustaining the desired performance in complex and vulnerable situations (Ponomarov \& Holcomb, 2009; Sun et al., 2020). The primary objective of the study is to analyze the relationship between ACO capabilities to operational performance through SCDO and SCR. The secondary objective of the study is to examine the role of environmental uncertainty (UNC) in the relationship of ACO capabilities to SCDO and SCR respectively.

It is hard to find evidence in the literature on the relationship between ACO and SCDO. Moreover, few studies have investigated the relationship between ACO and SCR as mediated by UNC, yet both impact operational performances. Hence, this study intends to answer the following questions:

RQ1. How are ACO, SC disruption orientation and supply chain (SC) resilience related to operational performance?

RQ2. What is the impact of environmental uncertainty on operational performance, given that it influences $A C O, S C$ disruption orientation and SC resilience?

The remainder of this paper is structured into six sections. The second section describes the elements that underpin supply chain disruption, resilience and analytics. The third section presents the theoretical model and hypothesis development. The fourth section describes the 
research design and the fifth section presents the results. Section six discusses the results including the implications for theory and practice. In section seven, the study is concluded. The appendix showcases the operationalization of constructs used in the study.

\section{Supply chain disruption, resilience and analytics}

The term supply chain management was first mentioned in the Financial Times in the 1980s. It started to become main stream in the 1990s with the establishment of the Supply Chain Council (1996) and later the Council for Supply Chain Management Professionals (2004). Sometime later, the two professional bodies merged to become the American Production and Inventory Control Society (APICS) (Alfalla-Luque \& Medina-López, 2009) due to the reason of its importance in supply chain (Golinska-Dawson et al., 2011). The need for advances in supply chain management have become pressing as companies are increasingly confronted with disruptions such as natural disasters, pandemic and political unrest (Ivanov, 2020a, 2020b; Marucheck et al., 2011). For instance, Nokia and Ericsson (cellular phone manufacturer) faced a shortage of radio frequency chip components due to a fire at a supplier's plant in March 2000. This incident prompted Nokia to change its product configuration to meet demand during the supply disruption. Ericsson, on the other hand, was slow to respond and lost sales of 400 million euros. This incident illustrates how SCR and organizational capabilities can save a firm during a supply chain disruption (BCG, 2006; Pettit et al., 2019; Tang, 2006). Similarly, in 1997, many US companies were unable to receive supplies from their Indonesian suppliers when the currency (Rupiah) was devalued by more than $50 \%$. Two businesses, The Limited and Warner Bros., nevertheless managed to receive their supplies on time because the supplies had been further outsourced to Li \& Fung in Hong Kong. This company responded by procuring from suppliers in other parts of Asia and helped Indonesian suppliers with loans and credit to ensure timely supplies. As these examples show, companies clearly need to focus on both internal and external capabilities in order to circumvent disruptions more easily (Karimi \& Walter, 2015; Teece, 2007; Teece \& Pisano, 2003).

In 1999, when the supply of memory chips was disrupted following an earthquake in Taiwan, Dell influenced its customers with a special price for those willing to buy computers using components produced in other countries, whereas Apple struggled to convince customers to accept a lower version of their computers. Dell displayed the capability to influence customers, which ultimately improved their revenue by $41 \%$ despite a supply chain disruption (Sheffi \& Rice., 2005). This example points to the need for SCDO, which better equips companies to pick up alerts quickly and ready themselves for organizational efforts (Golgeci \& Ponomarov, 2013). SCDO can be developed by analysing earlier events or by simulation-based methods that provide hints as to how a disruption can be avoided or how it can affect the organization (Ambulkar et al., 2015; Bode et al., 2011).

A parallel strategy is SCR, which enables the flow of information and physical goods to be quickly restored in the supply chain (Karimi \& Walter, 2015; Kolinski et al., 2020; Min et al., 2019; Ortas et al., 2014). Resilience in supply chains means tight collaboration in the form of risk-sharing with channel partners, ranging from suppliers to customers (Cavalcante et al., 2019; Heckmann et al., 2015; Pavlov et al., 2019). Capabilities like trusted networks, information exchanges and forecasting, ensuring visibility, and knowing the status of entities in real time are key to resilient supply chains (Saggi \& Jain, 2018). After a disruption, supply chains do not always return to the pre-disaster form but may instead move to a new state for delivering goods and services. An adequate degree of SCR enables the dynamic capabilities to handle the financial outcomes of a disruption and maintain control over supply chain 
structure and functioning. Further, resilience makes it more likely that companies will be able to extract hidden information and insights in order to design even more robust supply chains that contribute to operational performance (Shamim et al., 2019; Shorfuzzaman et al., 2019; Sun et al., 2018). Dynamic environments (where demand fluctuates) induce considerable uncertainty about supply chain functioning, and companies need to develop the dynamic capabilities of SCDO and resilience to achieve the desired operational performance (OP) (Teece et al., 2016; Winter, 2003). An organization's OP is measured by goods delivered on time, product quality maintained, capacity utilization, and a low rate of wastage in processes and inventory, all of which are difficult to control under environmental uncertainty (UNC) (Chowdhury et al., 2019; Helfat \& Winter, 2011; Shi \& Liao, 2015; Sreedevi \& Saranga, 2017). To achieve adequate control over these parameters of OP, companies need to ensure the right mix of risk resilience and disruption orientation for positive influence (Chopra \& Sodhi, 2014; Tomlin, 2006). Yet, to develop risk resilience and disruption orientation, it is critical for companies to use advanced analytics techniques (optimization, simulation and regression) to facilitate the decision-making process (Chae et al., 2014; Golinska-Dawson et al., 2015; Shi \& Liao, 2015). Techniques like data visualization help companies spot abnormal trends or signs of upcoming disruption (Chae et al., 2014; Teece \& Leih, 2016). Analytic capabilities also can be used to track buying trends and offer more appropriate products and services to consumers at lower cost (LaValle et al., 2011; Miah et al., 2017).

Analytics can further help companies gain a deeper understanding of cause and effect of processes and design their capabilities with the resources at hand to tackle disruptive situations (Helfat \& Winter, 2011; Kim et al., 2011, 2015). Resources are key to developing capabilities, while capabilities are the immediate means that companies use for economic gain (Hart \& Dowell, 2011). Therefore, ACO gives direction to the disruption orientation and type of resilience a firm may want to adopt, given the OP it has in mind (Grover et al., 2018; Kwon et al., 2014; LaValle et al., 2011; McAfee et al., 2012; Srinivasan \& Swink, 2018). The associations between ACO and SCDO and ACO and SCR can be impacted by UNC because manufacturing and supply chain dynamics cause recurrent variations in the mix of products, supply requirements, technical specifications, suppliers' need to adhere to frequent design changes, and the rising need for customization (Bode et al., 2011; Golgeci \& Ponomarov, 2013; Majdzik et al., 2016; Syed et al., 2020; Yu et al., 2019). Hence, it is appropriate to examine the relationships between ACO, SCDO, and SCR as dynamic capabilities for achieving OP under UNC. Figure 1 presents their relationships as dynamic capabilities to drive performance in competitive environments.

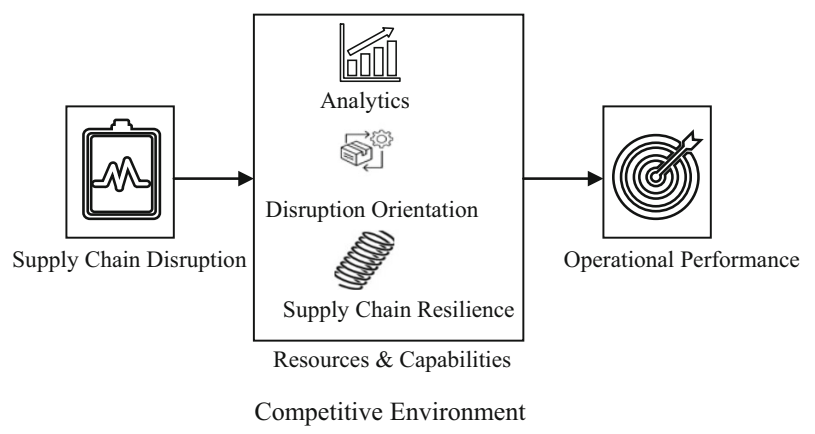

Fig. 1 Schematic diagram of achieving operational performance under UNC using the dynamic capabilities of ACO, SCDO and SCR ( Adapted from Ivanov et al., 2019) 


\section{Theoretical model and hypothesis development}

\subsection{The relationship among ACO, SC disruption orientation, SC resilience, and operational performance}

Several types of analytics are increasingly being used by companies to manage processes and analyze data from different sources and measure the actions directed at achieving the desired operational performance (Agarwal \& Dhar, 2014). Developing analytics capability can mould business operations for a smooth flow in uncertain environments (Gupta \& George, 2016; Saggi \& Jain, 2018). By using intelligent techniques, tools, setups and technologies, including mobile devices, companies gather information from social media and self-regulating technologies like the Internet of Things and Cloud Computing to develop adequate SCDO (Akter et al., 2020; Grover et al., 2018; Miah et al., 2017). Disruptions in supply chains point to the need for back-up plans, which themselves point to the need for appropriate amount of resilience (Min, 2019; Xia et al., 2000). A high degree of SCR can improve the responsiveness through the effective use of analytics and lead to auto-cycles of resilience (Golgeci \& Ponomarov, 2013). The dynamic capability of analytics allows companies to manage their supply chains seamlessly by reducing delays and sharing insights with partners so that they can act quickly to have impact on the overall operational performance (Kim et al., 2011; Tirkolaee et al., 2020). Hence, we propose:

H1a. ACO positively influences SC disruption orientation.

H1b. ACO positively influences SC resilience.

H1c. ACO positively influences operational performance.

\subsection{The relationship among SC disruption orientation, SC resilience and operational performance through ACO}

Achieving high operational performance, a critical component of strategic goals, is a major challenge for companies. In today's information era with its frequent disruptions, a disruption orientation is critical for reconfiguring and reorganizing dynamic capabilities to keep business operations on track (Kim et al., 2015; Teece \& Leih, 2016; Winter, 2003). Companies with creative and strategically useful SCDO can mitigate the impact of disruptions to a significant extent (Bode et al., 2011). This orientation needs to be aligned with multi-fold data emerging from a range of business activities (Shamim et al., 2019). Apart from adequate SCDO, companies need resilience to reconfigure their capabilities and resources to ensure a minimum impact on business operations and an adaptation to earlier or new stable state as fast as possible (Chae et al., 2014). SCR is further supported by diverse data on demand quantity, how supply chain partners are reacting, and the capabilities to influence operational performance (Hosseini \& Ivanov, 2019; Shao et al., 2018). Therefore, companies adopt analytics as a dynamic technological capability to achieve the desired operational performance (Mikalef et al., 2020). Hence, we propose: 
H2a. ACO positively influences operational performance through SC disruption orientation. H2b. ACO positively influences operational performance through SC resilience.

\subsection{The influence of environmental uncertainty on ACO with regard to SC disruption orientation, SC resilience and operation performance}

Today companies are open to more risks than ever before due to competition, regulatory requirements, demanding stakeholders and other market changes (Teece et al., 2016). This situation forces them to act quickly in making business decisions. A logical and methodical approach is thus needed to address decision-making in rapidly evolving markets (Kwon et al., 2014). Under environmental uncertainty, analytics is a dynamic capability to simulate and predict compelling insights to achieve operational performance. By following a three-step process (manage data, perform analytics and drive decisions), analytics helps companies design their SCDO more swiftly and effectively (Agarwal \& Dhar, 2014; Pigni et al., 2016) so that managers can make evidence-based decisions about developing even more significant SCDO (Shamim et al., 2019). In uncertain circumstances, ACO can help a firm's supply chain in terms of demand and visibility, procurement decisions, and seamless running of operations, which contribute to SCR (Bateman \& Bonanni, 2019). Therefore, companies should develop $\mathrm{ACO}$ if they are operating in an uncertain environment, as this will strengthen their operational performance through a dynamic mix of SCDO and resilience. Hence, we propose:

H3a. Environmental uncertainty enriches operational performance by strengthening the influence of ACO on SC disruption orientation.

H3b. Environmental uncertainty enriches operational performance by strengthening the influence of $\mathrm{ACO}$ on $\mathrm{SC}$ resilience.

Figure 2 depicts the theoretical model adopted in this study.

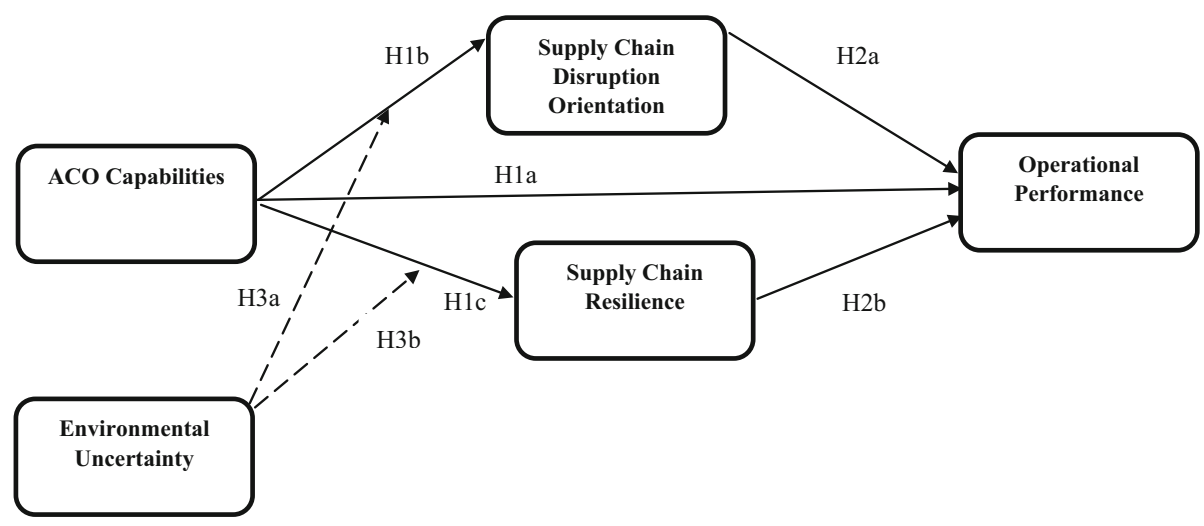

Fig. 2 Theoretical research framework 


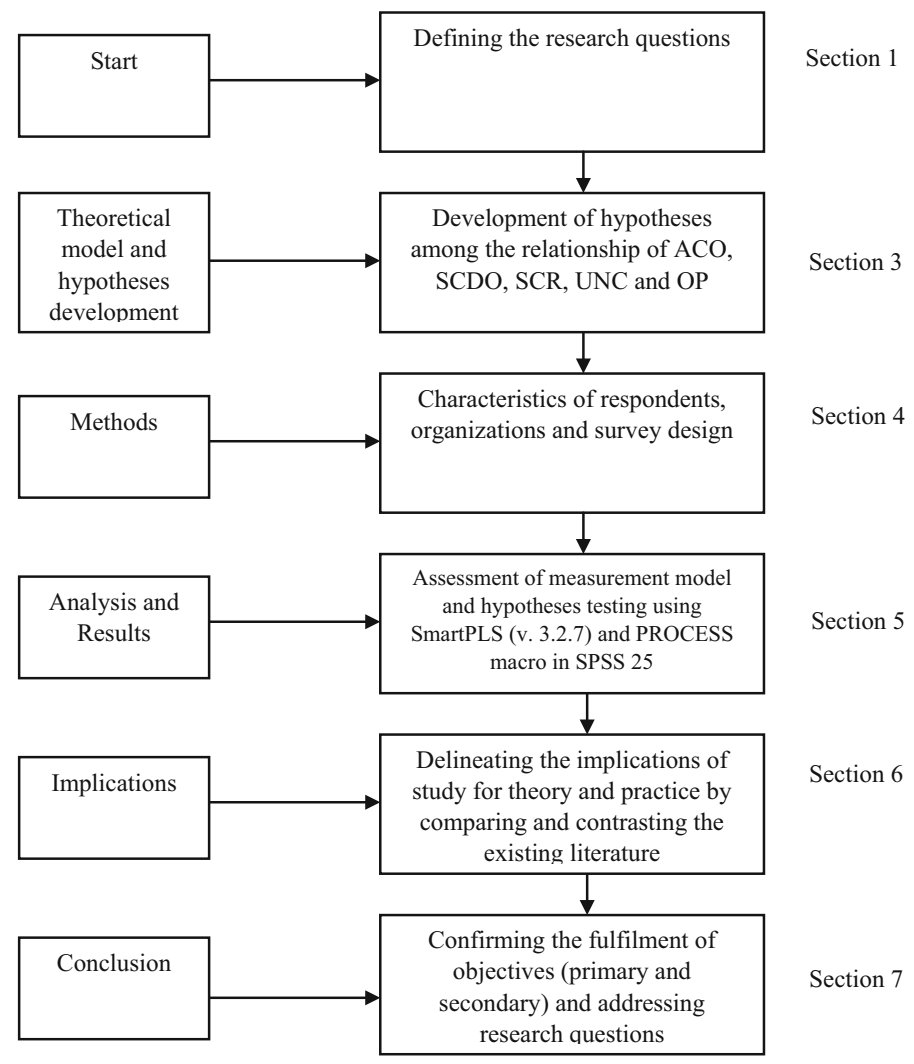

Fig. 3 Flowchart of research design

\section{Research methods}

\subsection{Research design}

The present study collected data from October 2019 to January 2020 using a structured questionnaire targeting about 3000 manufacturing companies in France. The manufacturing companies were identified in the DIANE ${ }^{1}$ database, which stores key information about 28,986 licensed manufacturing companies in France. Further respondents were narrowed down to those with enough experience in analytics, supply chain and operations management to answer the questions of the survey. After this, a sampling procedure was adopted to carry out the survey with parameters ranging from formatting to reaching out and collecting the responses (Dillman, 2011). This helped to design an accessible questionnaire for respondents. The confidentiality of information collected was assured to respondents. Three reminders were sent, once every two weeks, to increase the response rate. To ensure maximum involvement, it was assured to them that we would be sharing the research outcomes with them. In total, 405 completed responses were received, reflecting a $13.5 \%$ response rate. The completed questionnaires from various industries were collected, as shown in Fig. 3.

\footnotetext{
1 DIANE is one of the databases of Bureau van Dijk Electronic Publishing.
} 

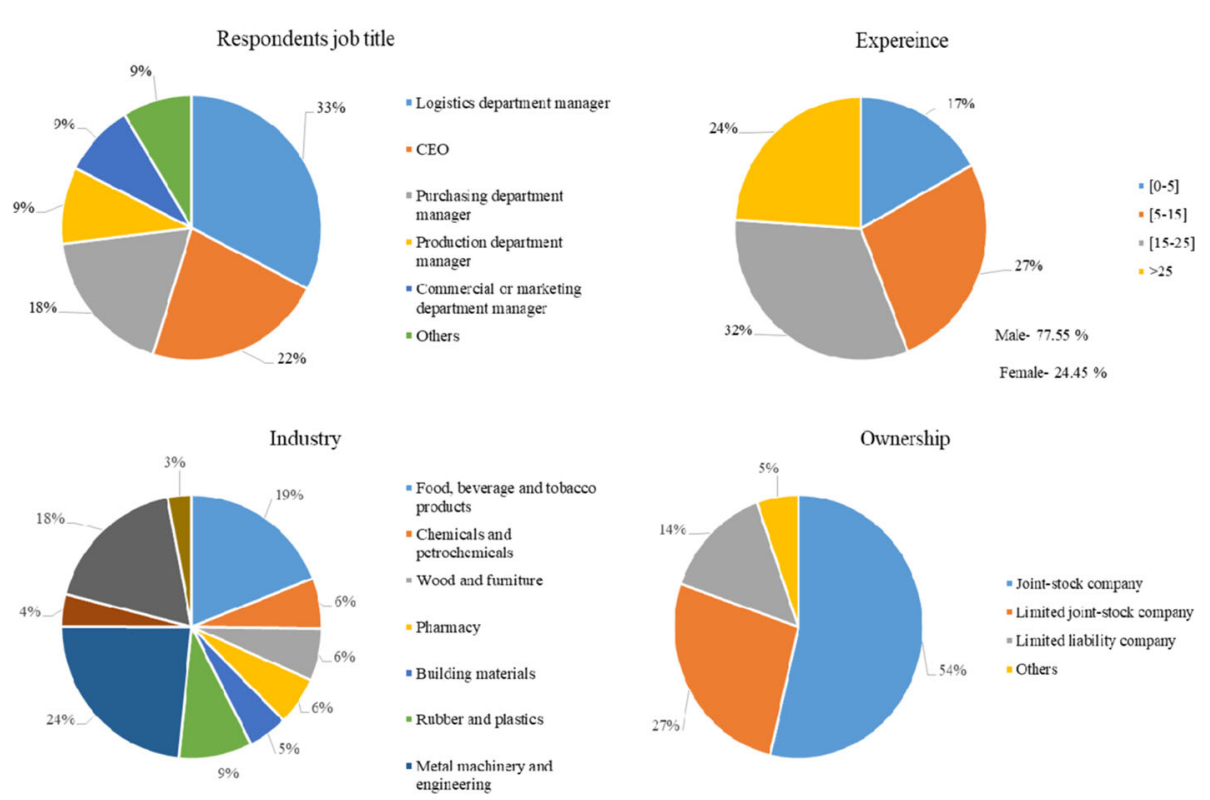

Fig. 4 Characteristics of respondents and organizations

The largest share was from the metal machinery and engineering sector (23.45\%), followed by the food, beverage and tobacco products industry $(19.01 \%)$, and the electronic products and electrical appliances sector (18.02\%). Most companies were medium-sized: $33.08 \%$, and $32.83 \%$ were large and $27.40 \%$ were small (see Fig. 4). Further a flow chart is developed (see Fig. 3) addressing the achievement of research objectives and questions.

This study employs 'a prior' and post-hoc power analyses (using the G*Power tool) to ensure the adequacy of sample size (Faul et al., 2009). To ensure sample adequacy, this study used a minimum value of $\mathrm{R}^{2}(0.10), 95 \%$ statistical power and three predictors (operational performance had the most predictors). The $G^{*}$ Power and 'a priori' analyses indicated 159 respondents for the sample size. In addition, the post-hoc $\mathrm{G}^{*}$ Power results for a sample size of 159 , minimum value of $\mathrm{R}^{2}(0.10)$, and three predictors pointed to a statistical power of 0.95 , which is above Cohen's reference. Hence, the adequacy of sample size was not a problem in the present study.

The early and late respondents were compared to test non-response bias (Cohen, 1988; Werner et al., 2007) and did so by conducting a t-test in terms of industry (respectively, $\mathrm{N}=203$ and $\mathrm{N}=202$ ). Findings revealed no significant difference in the industry $(\mathrm{t}=$ $1.521 ; p=0.129$ ) and confirmed that non-response bias was not a probable concern in the present study. Furthermore, the comparisons of respondents and non-respondents with regard to ownership characteristics showed no significant differences (Table 1). Thus, the non-response tests indicated that sample was representative with a low likelihood of nonresponse bias. A summary of the respondents' characteristics is provided in Fig. 4. 
Table 1 Results of tests for non-response

\begin{tabular}{llcc}
\hline $\begin{array}{l}\text { Non-response analysis for } \\
\text { ownership characteristics } \\
\text { of companies }\end{array}$ & $\begin{array}{l}\text { Respondents }(\mathrm{n}= \\
405)\end{array}$ & Non-respondents $(\mathrm{n}=60)$ & $\begin{array}{l}\text { Mann-Whitney } \\
\text { U-Test }\end{array}$ \\
\hline $\begin{array}{l}\text { Ownership } \\
\text { Joint-stock company }\end{array}$ & 232.07 & 239.25 & $\begin{array}{c}\mathrm{Z}=-0.447(p= \\
0.655)\end{array}$ \\
Limited liability company & 234.00 & 226.25 & $\begin{array}{c}\mathrm{Z}=-0.547(p= \\
0.584)\end{array}$ \\
Limited partnership & 234.30 & 224.25 & $\begin{array}{c}\mathrm{Z}=-0.906(p= \\
0.365)\end{array}$ \\
Others & 232.13 & 238.88 & $\begin{array}{c}\mathrm{Z}=-0.896(p= \\
0.370)\end{array}$ \\
\hline
\end{tabular}

\subsection{Common method variance}

To control the Common Method Variance (CMV), this study adopted procedural and statistical methods (Podsakoff et al., 2003). To comply with procedural design, the instrument was designed and developed in consultation with senior academics in supply chains, operations management and information systems. In addition, to ensure that the questions in the instrument maintained a logical flow, a pre-test study on manufacturing companies was conducted, where the instrument was divided into sections on ACO, SCR and SCDO, UNC and OP (Podsakoff et al., 2003). This further helped to align the measurement items for more clearly.

Further a post-hoc examination of CMV was performed using Harman's guidelines (1967) for a single factor test and marker variable methods (Malhotra et al., 2006). Six factors emerged (through eigenvalue-based unrotated exploratory factor analysis), indicating a one factor variance explanation of $26.135 \%$. Therefore, CMV was not a concern in this study, as a substantial amount of the variance was not owing to one factor (Fraj et al., 2015). Further, a PLS-SEM based marker variable method was employed in this study (Lee \& Hallak, 2018). A structural framework with and without an exogenous marker variable was employed, which further helped in predicting each construct. The legal status of the firm was the marker variable measured by a proxy as follows: "Is the legal form of firm 'Joint-stock company'? (Yes/No)." It should be noted that the marker variable and focal variables were collected simultaneously and in the same manner. The results indicated that the correlations between the marker and all other constructs in the model were very low: ACO: 0.105, SCDO: 0.123, SCR: 0.058, UNC: 0.015 and OP: 0.073 . Also, the effect of the marker construct on the endogenous construct of OP $(\beta=0.003)$ was very low and not significant. These results supported the appropriateness of the marker construct. The comparative analysis of the structural framework with and without the marker variable indicated no significant variances, and the theorized links presented supportive values and statistical significance. Hence, CMV was unlikely to be a concern.

\subsection{Construct measures}

All measures were drawn from well-established items in the research literature. ACO was assessed using an instrument developed by Srinivasan and Swink (2018). SCDO was assessed 
using an instrument developed by Bode et al. (2011) and used by Yu et al. (2019). SCR was measured with an instrument developed by Golgeci and Ponomarov (2013) and used by Yu et al. (2019). UNC was measured based on the work of Sreedevi and Saranga (2017). Finally, OP was assessed based on the work of Shi and Liao (2015).

\subsection{Data analysis}

The SmartPLS (v. 3.2.7) was employed to assess the measurement model and the PROCESS macro in SPSS 25 to investigate the structural model (Hayes, 2013). More specifically, the adequacy of the measurement model was assessed through estimation of (i) item loadings and composite reliabilities, (ii) convergent validity (AVE), and (iii) discriminant validity. Thereafter, and using the latent variable scores from SmartPLS as input, PROCESS produced estimates and bias-corrected $90 \%$ bootstrap confidence intervals for multiple mediation and moderated mediation effects. PROCESS can evaluate a multifaceted model representing both mediator and moderator variables and it has been extensively used in recent works (e.g. Wang et al., 2019).

An analyses using model 4 and model 7 of the PROCESS macro was conducted (Hayes, 2013). Thus, at first multiple mediation analysis was conducted (model 4 ) to test $\mathrm{H} 1 \mathrm{a} / \mathrm{b} / \mathrm{c}$ and H2a/b (Preacher \& Hayes, 2008). Further the study tested whether ACO affected OP directly and indirectly through the two mediators, SCDO and SCR. A linear regression analysis was performed to investigate the direct and indirect effects of ACO on OP as shown in Eqs. $(1,2$ and 3).

$$
\begin{gathered}
\mathrm{SCDO}=\propto_{\mathrm{SCDO}}+a_{1} \mathrm{ACO}+\varepsilon_{\mathrm{SCDO}} \\
\mathrm{SCR}=\propto_{\mathrm{SCR}}+a_{2} \mathrm{ACO}+\varepsilon_{\mathrm{SCR}} \\
\mathrm{OP}=\propto_{O P}+c^{\prime} \mathrm{ACO}+b_{1} \mathrm{SCDO}+b_{2} \mathrm{SCR}+b_{3} S I Z E+\varepsilon_{O P}
\end{gathered}
$$

The approximation of SCDO/SCR from ACO is determined by Eqs. (1 and 2), and Eq. (3) determines OP from ACO and SCDO/SCR. The regression of OP on ACO in Eq. (4) can also be utilized to estimate the total effect of ACO on OP.

$$
O P=\propto_{O P}+c A C O+b_{3}^{\prime} S I Z E+\varepsilon_{O P}
$$

Likewise, to validate the notion of normality in the sample spread of the total and particular indirect effects, a bootstrapping procedure was conducted.

To test $\mathrm{H} 3 \mathrm{a} / \mathrm{b}$, model 7 was used for first-stage moderated mediation model. Specifically, this model enabled to test whether the moderator variable UNC affected OP by impacting the linkages between ACO and both SCDO and SCR. Thus, using regression analysis, the first-stage model (moderated-mediation) can be estimated as shown below:

$$
\begin{gathered}
\mathrm{SCDO}=\propto_{\mathrm{SCDO}}+a_{1} A C O+a_{2} U N C+a_{3} A C O * U N C+\varepsilon_{\mathrm{SCDO}} \\
\mathrm{SCR}=\propto_{\mathrm{SCR}}+a_{1}^{\prime} A C O+a_{2}^{\prime} U N C+a_{3}^{\prime} A C O * U N C+\varepsilon_{\mathrm{SCR}} \\
\mathrm{OP}=\propto_{O P}+c^{\prime} A C O+b_{1} \mathrm{SCDO}+b_{2} \mathrm{SCR}+b_{3} S I Z E+\varepsilon_{O P}
\end{gathered}
$$

From these three Eqs. (5, 6 and 7), the indirect effect of ACO on OP is the product of the effect of ACO on SCDO and SCR indicated in Eq. (8):

$$
\left(a_{1}+a_{3} U N C\right) b_{1}+\left(a_{1}^{\prime}+a_{3}^{\prime} U N C\right) b_{2}=a_{1} b_{1}+a_{3} b_{1} U N C+a_{1}^{\prime} b_{2}+a_{3}^{\prime} b_{2} U N C
$$


The indirect effect represents a statistical mechanism through which ACO influences OP in the case of a linear relationship with moderator UNC. This indicates that the size or strength of a mechanism changes with changes in the moderator (Hayes, 2018).

\section{Results}

\subsection{Assessment of the measurement model}

As noted earlier, to check the adequacy of the measurement model in this study, the estimation of (i) item loadings along with composite reliabilities, (ii) convergent validity (AVE), and (iii) discriminant validity, was done. The reliability of the survey items in this regard was checked and found within the limits, as all loadings were above the threshold of 0.50 (Hair et al., 2012) and both Dillon-Goldstein's rho (composite reliability) and Cronbach's $\alpha$ values were above the minimum threshold of 0.60 (Hair et al., 2017) (Table 2). Also, the values of convergent validity for all constructs were above the threshold of 0.50 (Table 2).

A Fornell-Larcker's criterion and the heterotrait-monotrait ratio of correlations (HTMT) were used to ensure the discriminant validity in this study. For Fornell-Larcker's criterion, the square root of AVE for every construct should be greater than its correlation with all other constructs. Table 3 indicates the fulfillment of the criterion for all constructs. Further the discriminant validity through HTMT was assessed. The acceptable values for HTMT should be at least below the threshold of $90 \%(<0.90)$ (Henseler et al., 2015). The values of HTMT for all constructs varied from 0.085 to 0.491 (Table 3 ) in this study, which supported the discriminant validity of the constructs.

\subsection{Hypothesis testing}

Tables 4 and 5 indicate the estimated results of the multiple mediation models and the first-stage moderated mediation model. A framework for regression to view the signs of multicollinearity among the explanatory variables was employed. The outcome indicated that no variance inflation factors (VIFs) exceeded 10, and thus multicollinearity was not a potential concern (Hair et al., 2006).

In Table 4, the results showed positive and noteworthy associations between ACO as the independent variable and SCDO, SCR and OP. These results supported hypotheses H1a, H1b and H1c. Moreover, the results suggested positive and significant indirect effects between ACO and OP through both SCDO and SCR. This supported hypotheses H2a and H2b.

Table 5 shows the conditional indirect effects of ACO on OP through both SCDO and SCR. The conditional indirect effect of ACO on OP through SCDO was positive and significant when UNC was high $(90 \% \mathrm{CI}=[0.0005$ to 0.0742$])$, medium $(90 \% \mathrm{CI}=[0.0005$ to $0.0680])$ and low $(90 \% \mathrm{CI}=[0.0005$ to 0.0651$])$. However, the $\mathrm{CI}$ for the index of conditional moderated mediation by UNC includes zero ( $90 \% \mathrm{CI}=[-0.0005$ to 0.0122$])$. Therefore, it cannot be definitively concluded that UNC controls the indirect effect of ACO on OP through $\mathrm{SCDO}$, thus rejecting $\mathrm{H} 3 \mathrm{a}$. The conditional indirect effect of ACO on OP through SCR was positive and significant when UNC was high $(90 \% \mathrm{CI}=[0.0547$ to 0.1470$])$, medium $(90 \%$ $\mathrm{CI}=[0.0836$ to 0.1830$])$ and low $(90 \% \mathrm{CI}=[0.0988$ to 0.2363$])$. As the $\mathrm{CI}$ for the index of conditional moderated mediation by UNC did not contain zero $(90 \% \mathrm{CI}=[-0.0665$ to 0.0048]). Also, as shown in Fig. 5, the conditional indirect effect of ACO on OP through SCR was higher at a low level of UNC (coefficient $=0.1619$ ) while it was lower at a high level 
Table 2 Estimation of the measurement model parameters

\begin{tabular}{|c|c|c|c|c|}
\hline Constructs/measures & Loading & Cronbach's alpha $(\alpha)$ & $\begin{array}{l}\text { Composite } \\
\text { reliability }(\mathrm{CR})\end{array}$ & $\begin{array}{l}\text { Average } \\
\text { variance } \\
\text { extracted } \\
\text { (AVE) }\end{array}$ \\
\hline
\end{tabular}

Analytics Capability of an

0.907

0.931

0.729

Organization (ACO)

$\begin{array}{ll}\text { ACO1 } & 0.846 \\ \mathrm{ACO} 2 & 0.825 \\ \mathrm{ACO} 3 & 0.884 \\ \mathrm{ACO} 4 & 0.871 \\ \mathrm{ACO} 5 & 0.843\end{array}$

Supply Chain Disruption Orientation (SCDO)

$\begin{array}{ll}\text { SCDO1 } & 0.514 \\ \text { SCDO2 } & 0.592 \\ \text { SCDO3 } & 0.898 \\ \text { SCDO4 } & 0.881\end{array}$

Supply Chain Resilience (SCR)

0.843

0.884

0.559

$\begin{array}{ll}\text { SCR1 } & 0.773 \\ \text { SCR2 } & 0.711 \\ \text { SCR3 } & 0.745 \\ \text { SCR4 } & 0.745 \\ \text { SCR5 } & 0.798 \\ \text { SCR6 } & 0.711\end{array}$

Environmental Uncertainty (UNC)

0.817

0.863

0.515

UNC1

0.720

UNC2 0.747

UNC3 0.622

UNC4 $\quad 0.835$

UNC5 $\quad 0.698$

UNC6 $\quad 0.665$

Operational Performance (OP)

$\begin{array}{ll}\text { OP1 } & 0.755 \\ \text { OP2 } & 0.647 \\ \text { OP3 } & 0.852 \\ \text { OP4 } & 0.833 \\ \text { OP5 } & 0.682\end{array}$

Size

SIZE

1.000

1.000

1.000

1.000

0.870

0.575

0.811

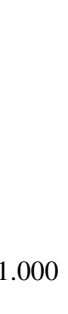


Table 3 Discriminant validity coefficients

\begin{tabular}{lllllll}
\hline & ACO & SCDO & SCR & UNC & OP & SIZE \\
\hline ACO & $\mathbf{0 . 8 5 4}$ & 0.405 & 0.401 & 0.182 & 0.394 & 0.318 \\
SCDO & 0.454 & $\mathbf{0 . 7 4 1}$ & 0.451 & 0.155 & 0.329 & 0.221 \\
SCR & 0.446 & 0.463 & $\mathbf{0 . 7 4 8}$ & 0.052 & 0.423 & 0.006 \\
UNC & 0.193 & 0.189 & 0.085 & $\mathbf{0 . 7 1 8}$ & 0.076 & 0.046 \\
OP & 0.457 & 0.359 & 0.491 & 0.113 & $\mathbf{0 . 7 5 8}$ & 0.152 \\
SIZE & 0.334 & 0.274 & 0.088 & 0.108 & 0.179 & $\mathbf{1 . 0 0 0}$ \\
\hline
\end{tabular}

The square root of variance common among constructs and their variables (AVE) is represented by the diagonal elements in bold. All those values above the values in bold are correlations between constructs and below are the HTMT values

Table 4 Prediction of operational performance: Mediation effects of disruption and resilience in supply chains

\begin{tabular}{|c|c|c|c|c|c|c|}
\hline \multirow{2}{*}{$\begin{array}{l}\text { Dependent } \\
\text { variable }\end{array}$} & \multicolumn{2}{|l|}{ SCDO } & \multicolumn{2}{|l|}{ SCR } & \multicolumn{2}{|l|}{$\mathrm{OP}$} \\
\hline & Coefficien & t-stat & Coefficient & t-stat & Coefficient & t-stat \\
\hline \multicolumn{7}{|c|}{ Independent variable } \\
\hline $\begin{array}{l}\text { Analytics } \\
\text { Capabilities of } \\
\text { an } \\
\text { Organization } \\
\text { (ACO) }\end{array}$ & 0.3723 & $6.9003^{* * *}$ & 0.4445 & $8.1977^{* * *}$ & 0.2188 & $3.9476^{* * *}$ \\
\hline \multicolumn{7}{|l|}{ Mediator } \\
\hline $\begin{array}{c}\text { Supply Chain } \\
\text { Disruption } \\
\text { Orientation }\end{array}$ & - & - & - & - & 0.0962 & $1.7054^{*}$ \\
\hline $\begin{array}{l}\text { Supply Chain } \\
\text { Resilience }\end{array}$ & - & - & - & - & 0.2919 & $4.6027^{* * *}$ \\
\hline \multicolumn{7}{|l|}{ Control variables } \\
\hline Firm size & 0.1020 & 1.9588 & -0.1355 & $-{ }^{-} .7033^{* * *}$ & 0.0591 & 1.2935 \\
\hline $\mathrm{R}^{2}$ & 0.4162 & & 0.4214 & & 0.5004 & \\
\hline$F(d f 1$, df2) & 35.1505 & 402) & $33.6136(2$. & & 24.2445 & $400)$ \\
\hline \multicolumn{2}{|c|}{ Direct and indirect effects } & Effect & $t$ & \multicolumn{2}{|c|}{ Lower $90 \%$ CI } & Upper $90 \% \mathrm{CI}$ \\
\hline \multicolumn{2}{|c|}{ Total effect of ACO on OP } & 0.3844 & $7.0653^{* * *}$ & 0.2947 & \multicolumn{2}{|r|}{0.4741} \\
\hline \multicolumn{2}{|c|}{ Direct effect of ACO on OP } & 0.2188 & $3.9476^{* * *}$ & 0.1274 & \multicolumn{2}{|r|}{0.3102} \\
\hline \multicolumn{2}{|c|}{$\begin{array}{l}\text { Indirect effect of ACO on } \\
\text { OP (through SCDO) }\end{array}$} & 0.0358 & - & 0.0016 & \multicolumn{2}{|r|}{0.0714} \\
\hline \multicolumn{2}{|c|}{$\begin{array}{l}\text { Indirect effect of ACO on } \\
\text { OP (through SCR) }\end{array}$} & 0.1297 & - & 0.0827 & \multicolumn{2}{|r|}{0.1836} \\
\hline
\end{tabular}

*** $p<0.01, * * p<0.05, * p<0.10 ; \mathrm{CI}$ : Confidence interval 
Table 5 Prediction of operational performance: Moderated mediation effects of environmental uncertainty

First-stage moderated mediation

\begin{tabular}{|c|c|c|c|c|c|c|c|}
\hline \multirow{2}{*}{$\begin{array}{l}\text { Dependent } \\
\text { variable }\end{array}$} & \multicolumn{2}{|l|}{$S C D O$} & \multicolumn{2}{|l|}{$S C R$} & \multicolumn{3}{|c|}{$O P$} \\
\hline & Coefficient & t-stat & Coefficient & t-stat & \multicolumn{2}{|c|}{ Coefficient } & t-stat \\
\hline \multicolumn{8}{|c|}{ Independent variable } \\
\hline $\begin{array}{l}\text { Analytics } \\
\text { Capabilities } \\
\text { of an } \\
\text { Organization } \\
\text { (ACO) }\end{array}$ & 0.3575 & $6.3988^{* * *}$ & 0.4435 & $8.1118^{* * *}$ & \multicolumn{2}{|c|}{0.2188} & $3.9476^{* * *}$ \\
\hline \multicolumn{8}{|l|}{ Mediators } \\
\hline $\begin{array}{c}\text { Supply Chain } \\
\text { Disruption } \\
\text { Orientation }\end{array}$ & - & - & - & - & \multicolumn{2}{|c|}{0.0962} & $1.7054^{*}$ \\
\hline \multicolumn{5}{|l|}{ Supply Chain } & \multicolumn{2}{|c|}{0.2919} & $4.6027^{* * *}$ \\
\hline Resilience & - & - & - & - & & & \\
\hline \multicolumn{8}{|l|}{ Moderator } \\
\hline $\begin{array}{l}\text { Environmental } \\
\text { uncertainty } \\
\text { (UNC) }\end{array}$ & 0.0852 & $1.8865^{*}$ & -0.0223 & -0.4348 & \multicolumn{2}{|l|}{-} & - \\
\hline \multicolumn{8}{|c|}{ Control variables } \\
\hline Firm size & 0.1036 & $1.9938^{* *}$ & -0.1380 & $2.7553^{* * *}$ & \multicolumn{2}{|c|}{0.0591} & 1.2935 \\
\hline \multicolumn{8}{|c|}{ Interaction terms } \\
\hline $\mathrm{ACO} \times \mathrm{UNC}$ & 0.0234 & 0.4541 & -0.1109 & $-1.8237^{*}$ & \multicolumn{2}{|l|}{-} & - \\
\hline $\mathrm{R}^{2}$ & 0.4253 & 0.4370 & \multicolumn{2}{|l|}{0.5004} & & & \\
\hline $\mathrm{F}(\mathrm{df} 1, \mathrm{df} 2)$ & $\begin{array}{l}20.9120(4 . \\
400)\end{array}$ & $\begin{array}{r}16.6927 \\
(4.400)\end{array}$ & \multicolumn{2}{|l|}{$\begin{array}{c}24.2445(4 . \\
400)\end{array}$} & & & \\
\hline \multicolumn{2}{|c|}{ Conditional indirect effects } & Effect & Boot SE & \multicolumn{2}{|l|}{ Boot Lower $90 \% \mathrm{CI}$} & \multicolumn{2}{|c|}{ Boot Upper $90 \% \mathrm{CI}$} \\
\hline \multicolumn{8}{|c|}{$A C O$ on $O P$ through $S C D O$} \\
\hline \multicolumn{2}{|l|}{ Low UNC } & 0.0321 & 0.0198 & 0.0005 & \multicolumn{3}{|c|}{0.0651} \\
\hline \multicolumn{2}{|l|}{ Medium UNC } & 0.0344 & 0.0205 & 0.0005 & \multicolumn{3}{|c|}{0.0680} \\
\hline \multicolumn{2}{|l|}{ High UNC } & 0.0367 & 0.0226 & 0.0005 & \multicolumn{3}{|c|}{0.0742} \\
\hline \multicolumn{2}{|c|}{ Index of moderated mediation } & 0.0023 & 0.0055 & -0.0055 & & 0.0122 & \\
\hline$A C O$ on $O P$ thr & gh SCR & & & & & & \\
\hline Low UNC & & 0.1619 & 0.0418 & 0.0988 & & 0.2363 & \\
\hline Medium UNC & & 0.1295 & 0.0301 & 0.0836 & & 0.1830 & \\
\hline High UNC & & 0.0971 & 0.0281 & 0.0547 & & 0.1470 & \\
\hline Index of moder & d mediation & -0.0324 & 0.0189 & -0.0665 & & -0.00 & \\
\hline
\end{tabular}

*** $p<0.01, * * p<0.05, * p<0.10 ; \mathrm{CI}$ : Confidence interval 


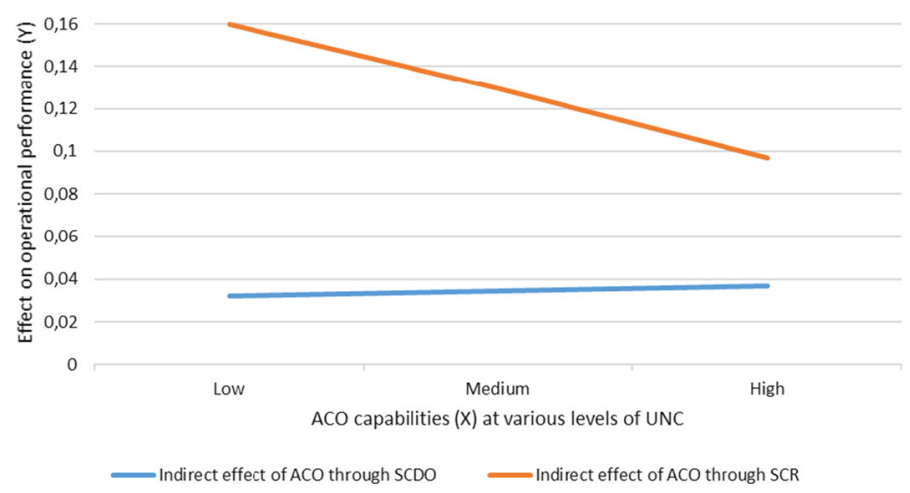

Fig. 5 Conditional indirect effects of big data analytics on operational performance through both supply chain disruption orientation (SCDO) and supply chain resilience (SCR)

Table 6 Hypothesis results

\begin{tabular}{lll}
\hline Hypothesis & Description & Status \\
\hline $\mathrm{H} 1 \mathrm{a}$ & ACO positively influences SC disruption orientation & Supported \\
$\mathrm{H} 1 \mathrm{~b}$ & ACO positively influences SC resilience & Supported \\
$\mathrm{H} 1 \mathrm{c}$ & ACO positively influences operational performance & Supported \\
$\mathrm{H} 2 \mathrm{a}$ & ACO positively influences operational performance & Supported \\
& through SC disruption orientation & \\
$\mathrm{H} 2 \mathrm{~b}$ & $\begin{array}{l}\text { ACO positively influences operational performance } \\
\text { through SC resilience }\end{array}$ & Supported \\
& $\begin{array}{l}\text { Environmental uncertainty enriches operational } \\
\text { performance by strengthening the influence of ACO on }\end{array}$ & Not Supported \\
$\mathrm{H} 3 \mathrm{a}$ & $\begin{array}{l}\text { SC disruption orientation } \\
\text { Environmental uncertainty enriches operational } \\
\text { performance by strengthening the influence of ACO on }\end{array}$ & Supported \\
H3b & SC resilience & \\
& &
\end{tabular}

of UNC (coefficient $=0.0971$ ). Overall, it can be concluded that UNC positively moderates the indirect effect of ACO on OP through SCR, thus supporting H3b. Table 6 summarizes the status of hypotheses after analysis.

\section{Discussion}

Multiple mediation and moderated mediation analyses suggested some interesting and exciting contributions to the theoretical discussions on the Analytics Capabilities of an Organization, Supply Chain Disruption Orientation, Supply Chain Resilience, and Operational Performance under the impact of Environmental Uncertainty. This study incorporated concepts from three fields of study: information systems, supply chains, and strategic management. Few studies in the literature have done so, instead drawing on information processing theory (OIPT), institutional theory or RCV along with DCV (Chae et al., 2014; Kim et al., 
2011, 2015; Wamba et al., 2020). On this basis, this study claim unique contributions to theory and practice.

\subsection{Theoretical contributions}

This study makes three main contributions. First, it empirically supports the view that dynamic capabilities are not universal. It strengthens the frontiers of dynamic capabilities theory, which is critical for expanding grounded theory as a way to enrich the literature. Second, the present study confirms the key role of environmental uncertainty in the relationships between the ACO, SCDO, SCR and OP of an organization. Hence, it addresses two main research questions: How are ACO, SC disruption orientation, and SC resilience related to operational performance? And what is the impact of environmental uncertainty on operational performance, given that it influences ACO, SC disruption orientation and SC resilience? These are critical research questions in information systems, operations and supply chain management (Shamim et al., 2019; Yu et al., 2019). Earlier studies in these fields (Ambulkar et al., 2015; Bode et al., 2011; Chen et al., 2012; Kwon et al., 2014; Miah et al., 2017; Saggi \& Jain, 2018) agree with the role of analytics as a dynamic capability and its impact on operations and supply chains. However, a consensus on how analytics capability influences a firm's supply chain disruption orientation is lacking. This was further supported by Sheffi and Rice (2005), who noted that supply chains would be better positioned in their disruption orientation if they drew on Dell's data-based insights following the 1999 earthquake in Taiwan. Although Oke and Gopalakrishnan (2009) highlighted the classification of risk categories and mitigation strategies, in the age of information it is critical to harness analytics as a capability that can further influence SCDO, which seems crucial in today's dynamic environment (Chae et al., 2014; DuHadway et al., 2019; Srinivasan \& Swink, 2018).

Although this study reports on the means for achieving operational performance, the findings particularly indicate that OP is influenced by dynamic capabilities such as ACO, SCDO and SCR in company operations, which further challenges the traditional view of supply chain classification (efficient/risk hedging, responsive and agile) (Hassini et al., 2008; Lalmazloumian et al., 2016). It is suggested that supply chains can facilitate better operational performances by mobilizing the dynamic capabilities that emerge from analytics. Third, this study integrates aspects of dynamic capabilities under diverse impacts of environmental uncertainty. It can be difficult to orient a specific strategy to combat disruption in supply chains, especially in highly dynamic environments (Teece et al., 2016). Hence, to achieve the desired operational performance, companies may need to shift between various strategies or use them in an on-and-off manner to tackle a given situation.

\subsection{Managerial implications}

The findings of present study can act as guidelines for chief information officers, chief supply chain officers and other top executives who are thinking about investing in analytics-enabled dynamic capabilities for their organizations. They need to carefully consider the following: (i) the capability of their supply chains to recognize dynamic fluctuations due to both upstream and downstream activities, (ii) the capability to orient their supply chains from a disruptionpreparedness perspective, and (iii) the ability of their supply chains to recover from disruptive events to ensure the desired operational performance. This study suggests that strengthening analytics capabilities will help companies acquire dynamic resilience and disruption orientation in their supply chains in order to improve operational performance. Analytics 
also facilitates the emergence of dynamic capabilities to advance operational performance by optimizing the association between ACO and SCR under the influence of UNC. Some routines in companies are standard and others are dynamic in nature. Therefore, to ensure efficient decision-making processes in dynamic environment, managers need to regularly align their supply chain strategies and build capabilities to increase competitive advantage. Environmental uncertainty has the potential to change the fate of businesses and may well render existing capabilities irrelevant due to changing circumstances (Swamidass \& Newell, 1987). Accordingly, managers need to recognize and safeguard analytics-enabled dynamic capabilities with regard to decisions to make supply chains better prepared and responsive to disruptions while simultaneously achieving adequate operational performance.

\subsection{Limitations and future scope of research}

The present study has a few limitations. The lens of DCV was used in this study and thus it is limited by context insensitivity (Teece, 2014). DCV also cannot be used to categorise the right mix of options that may make organizational capabilities much more respectable (Schilke, 2014). Although the present study tried to circumvent this limitation by employing a contingency view of companies (moderating impact of environmental uncertainty), it is recommended that researchers can consider more dynamic conditions such as flexibility to achieve greater operational performance in the future. The present study also can have limitations in terms of endogeneity and common method bias (CMB), since it is surveybased (Guide \& Ketokivi, 2015; Sande \& Ghosh, 2018). Though the study took precautions to safeguard endogeneity and CMB and note that either longitudinal or multi-informant data from a single firm can help with this issue. It may be interesting to examine how analytics capabilities can be further enhanced through big data and other means (Wamba et al., 2018). Furthermore, the results of this study can be investigated in diverse contexts to address the limitations.

\section{Conclusion}

This study examines analytics-enabled dynamic capabilities that further strengthen the supply chain system to achieve greater operational performance. Through the lens of DCV, this study analyses how analytics capabilities help build supply chain resilience and supply chain disruption orientation. The present study also assumes the influence of uncertain environment and shows that they strengthen the dynamic capabilities for the ultimate objective of enhanced operational performance. Addressing the objectives, this study opens a potentially enriching debate on the association between dynamic capabilities and environmental uncertainty. The findings indicate positive influence of UNC in the link between ACO and SCR to derive operational performance, as compared to the link between ACO and SCDO. In brief, the findings demonstrate that $\mathrm{ACO}$ has a critical and superior impact on operational performance, as opposed to earlier studies that have presented different dynamics. The role of UNC in the link between ACO and SCDO and SCR has not yet been studied in detail. To summarize, the present study offers theory-based food for thought and reasoning around analytics-enabled dynamic capabilities and further clarifies the need for capabilities related to SCDO and SCR. This study presents a more comprehensive understanding about the design of SCR and SCDO through ACO to achieve the desired operational performance in an era of accelerating uncertainty. Further studies can be conducted on the quickly changing landscape 
such as technology, laws and regulations, regional and international politics and how analytics capability of organizations can play a critical role in deriving the operational performance. These issues can be better addressed by a case-based study, which will help correlate theory with analytics capabilities for better supply chain management and operational performance.

\section{Appendix}

Construct items.

\begin{tabular}{|c|c|c|}
\hline Construct & \multicolumn{2}{|l|}{ Items Indicators } \\
\hline \multirow{6}{*}{$\begin{array}{l}\text { Analytics } \\
\text { Capabilities of an } \\
\text { Organization } \\
(A C O)\end{array}$} & \multicolumn{2}{|c|}{ Please use the scale to indicate the most appropriate response: } \\
\hline & \multicolumn{2}{|c|}{$\begin{array}{l}\text { ACO1In our organization, we use advanced analytics techniques (e.g., } \\
\text { simulation, optimization, regression) to improve decision-making }\end{array}$} \\
\hline & $\mathrm{ACO} 2$ & $\begin{array}{l}\text { In our company, we use a wide } \\
\text { variety of data sources to } \\
\text { advance decision-making }\end{array}$ \\
\hline & $\mathrm{ACO} 3$ & $\begin{array}{l}\text { In our organization we use data } \\
\text { visualization techniques (e.g., } \\
\text { dashboards) to assist users to } \\
\text { decision-makers in } \\
\text { understanding complex } \\
\text { information }\end{array}$ \\
\hline & $\mathrm{ACO} 4$ & $\begin{array}{l}\text { Our organization's use of } \\
\text { dashboards helps display } \\
\text { information for undertaking } \\
\text { root cause analysis and } \\
\text { ensuring continuous } \\
\text { improvement }\end{array}$ \\
\hline & $\mathrm{ACO} 5$ & $\begin{array}{l}\text { Our organization uses dashboard } \\
\text { applications/information in } \\
\text { communication devices (e.g., } \\
\text { smart phones, computers) }\end{array}$ \\
\hline \multirow{3}{*}{$\begin{array}{l}\text { Supply chain } \\
\text { disruption } \\
\text { orientation } \\
\text { (SCDO) }\end{array}$} & \multicolumn{2}{|c|}{$\begin{array}{l}\text { Please indicate how much you agree or disagree with each of the following } \\
\text { statements: }\end{array}$} \\
\hline & SCDO1 & $\begin{array}{l}\text { We feel the need to be alert for } \\
\text { possible supply chain } \\
\text { disruptions at all times }\end{array}$ \\
\hline & SCDO2 & $\begin{array}{l}\text { We recognize that supply chain } \\
\text { disruptions are always looming }\end{array}$ \\
\hline
\end{tabular}




\begin{tabular}{|c|c|c|}
\hline \multirow[t]{3}{*}{ Construct } & \multicolumn{2}{|l|}{ Items Indicators } \\
\hline & $\mathrm{SCDO} 3$ & $\begin{array}{l}\text { We think a lot about how a } \\
\text { supply chain disruption could } \\
\text { have been avoided }\end{array}$ \\
\hline & $\mathrm{SCDO} 4$ & $\begin{array}{l}\text { After a supply chain disruption } \\
\text { has occurred, it is thoroughly } \\
\text { analyzed }\end{array}$ \\
\hline \multirow[t]{7}{*}{$\begin{array}{l}\text { Supply chain } \\
\text { resilience }(S C R)\end{array}$} & \multicolumn{2}{|c|}{$\begin{array}{l}\text { Please indicate how much you agree or disagree with each of the following } \\
\text { statements: }\end{array}$} \\
\hline & SCR1 & $\begin{array}{l}\text { Our company's supply chain is } \\
\text { able to adequately respond to } \\
\text { unexpected disruptions by } \\
\text { quickly restoring its product } \\
\text { flow }\end{array}$ \\
\hline & SCR2 & $\begin{array}{l}\text { Our company's supply chain can } \\
\text { quickly return to its original } \\
\text { state after being disrupted }\end{array}$ \\
\hline & SCR3 & $\begin{array}{l}\text { Our company's supply chain can } \\
\text { move to a new, more desirable } \\
\text { state after being disrupted }\end{array}$ \\
\hline & SCR4 & $\begin{array}{l}\text { Our company's supply chain is } \\
\text { well prepared to deal with the } \\
\text { financial outcomes of supply } \\
\text { chain disruptions }\end{array}$ \\
\hline & SCR5 & $\begin{array}{l}\text { Our company's supply chain has } \\
\text { the ability to maintain a desired } \\
\text { level of control over structure } \\
\text { and function at the time of } \\
\text { disruption }\end{array}$ \\
\hline & SCR6 & $\begin{array}{l}\text { Our firm's supply chain has the } \\
\text { ability to extract meaning and } \\
\text { useful knowledge from } \\
\text { disruptions and unexpected } \\
\text { events }\end{array}$ \\
\hline \multirow[t]{7}{*}{$\begin{array}{l}\text { Environmental } \\
\text { uncertainty }(U N C)\end{array}$} & \multicolumn{2}{|c|}{$\begin{array}{l}\text { Please indicate how much you agree or disagree with each of the following } \\
\text { statements: }\end{array}$} \\
\hline & UNC1 & $\begin{array}{l}\text { Demand fluctuates drastically } \\
\text { from week to week }\end{array}$ \\
\hline & UNC2 & $\begin{array}{l}\text { Total manufacturing volume } \\
\text { fluctuates drastically from } \\
\text { week to week }\end{array}$ \\
\hline & UNC3 & $\begin{array}{l}\text { The mix of products you produce } \\
\text { changes drastically from week } \\
\text { to week }\end{array}$ \\
\hline & UNC4 & $\begin{array}{l}\text { Supply requirements (volume } \\
\text { and mix) vary drastically from } \\
\text { week to week }\end{array}$ \\
\hline & UNC5 & $\begin{array}{l}\text { Products are characterized by a } \\
\text { lot of technical modifications }\end{array}$ \\
\hline & UNC6 & $\begin{array}{l}\text { Suppliers frequently need to } \\
\text { carry out modifications to the } \\
\text { parts/components they deliver } \\
\text { to your plant }\end{array}$ \\
\hline
\end{tabular}




\begin{tabular}{lll}
\hline Construct & Items Indicators & \\
\hline $\begin{array}{l}\text { Operational } \\
\text { Performance }(O P)\end{array}$ & $\begin{array}{l}\text { Please indicate the extent to which your company has achieved all of the } \\
\text { following over the past 12 months: }\end{array}$ \\
& OP1 & $\begin{array}{c}\text { Increase in the amount of goods } \\
\text { delivered on time }\end{array}$ \\
& OP2 & Decrease in inventory \\
OP3 & Decrease in scrap rate \\
OP4 & Promotion of product quality \\
OP5 & Improved capacity utilization \\
\hline
\end{tabular}

\section{References}

Agarwal, R., \& Dhar, V. (2014). Big data, data science, and analytics: The opportunity and challenge for IS research. Information Systems Research, 25(3), 443-448.

Akter, S., Michael, K., Uddin, M. R., McCarthy, G., \& Rahman, M. (2020). Transforming business using digital innovations: The application of AI, blockchain, cloud and data analytics. Annals of Operations Research. https://doi.org/10.1007/s10479-020-03620-w

Alfalla-Luque, R., \& Medina-López, C. (2009). Supply chain management: Unheard of in the 1970s, core to today's company. Business History, 51(2), 202-221.

Ambulkar, S., Blackhurst, J., \& Grawe, S. (2015). Firm's resilience to supply chain disruptions: Scale development and empirical examination. Journal of Operations Management, 33, 111-122.

Baghersad, M., \& Zobel, C. W. (2021). Assessing the extended impacts of supply chain disruptions on firms: An empirical study. International Journal of Production Economics, Forthcoming. https://doi.org/10. 1016/j.ijpe.2020.107862

Barnett, W. P., \& Pontikes, E. G. (2008). The Red Queen, success bias, and organizational inertia. Management Science, 54(7), 1237-1251.

Bateman, A., \& Bonanni, L. (2019). What supply chain transparency really means. Harvard Business Reviewhttps://hbr.org/2019/08/what-supply-chain-transparency-really-means

BCG (2006). Creating the optimal supply chain. Accessed on 12th August, 2020-https://knowledge.wharton. upenn.edu/special-report/creating-the-optimal-supply-chain/

Bode, C., Wagner, S. M., Petersen, K. J., \& Ellram, L. M. (2011). Understanding responses to supply chain disruptions: Insights from information processing and resource dependence perspectives. Academy of Management Journal, 54(4), 833-856.

Cavalcante, I. M., Frazzon, E. M., Forcellini, F. A., \& Ivanov, D. (2019). A supervised machine learning approach to data-driven simulation of resilient supplier selection in digital manufacturing. International Journal of Information Management, 49, 86-97.

Chae, B. K., Yang, C., Olson, D., \& Sheu, C. (2014). The impact of advanced analytics and data accuracy on operational performance: A contingent resource based theory (RBT) perspective. Decision Support Systems, 59, 119-126.

Chen, D. Q., Preston, D. S., \& Swink, M. (2015). How the use of big data analytics affects value creation in supply chain management. Journal of Management Information Systems, 32(4), 4-39.

Chen, H., Chiang, R. H., \& Storey, V. C. (2012). Business intelligence and analytics: From big data to big impact. MIS Quarterly, 36(4), 1165-1188.

Chopra, S., \& Sodhi, M. S. (2004). Supply-chain breakdown. MIT Sloan Management Review, 46(1), 53-61.

Chopra, S., \& Sodhi, M. S. (2014). Reducing the risk of supply chain disruptions. MIT Sloan Management Review, 55(3), 72-80.

Chowdhury, M. M. H., Quaddus, M., \& Agarwal, R. (2019). Supply chain resilience for performance: Role of relational practices and network complexities. Supply Chain Management: An International Journal, 24(5), 659-676.

Cohen, J. (1988). Statistical power analysis for the behavioral sciences (2nd ed.). USA: Lawrence Erlbaum Associates.

Côrte-Real, N., Oliveira, T., \& Ruivo, P. (2017). Assessing business value of big data analytics in European firms. Journal of Business Research, 70, 379-390. 
Dillman, D. A. (2011). Mail and Internet surveys: The tailored design method - 2007 update with new Internet, visual, and mixed-mode guide. Wiley.

Downes, L., \& Nunes, P. (2013). Big bang disruption. Harvard Business Review, 44-56.

Dubey, R., Gunasekaran, A., Childe, S. J., Papadopoulos, T., Luo, Z., \& Roubaud, D. (2020). Upstream supply chain visibility and complexity effect on focal company's sustainable performance: Indian manufacturers' perspective. Annals of Operations Research, 290(1), 343-367.

DuHadway, S., Carnovale, S., \& Hazen, B. (2019). Understanding risk management for intentional supply chain disruptions: Risk detection, risk mitigation, and risk recovery. Annals of Operations Research, 283(1), 179-198.

Faul, F., Erdfelder, E., Buchner, A., \& Lang, A. G. (2009). Statistical power analyses using G* Power 3.1: Tests for correlation and regression analyses. Behavior Research Methods, 41(4), 1149-1160.

Fraj, E., Matute, J., \& Melero, I. (2015). Environmental strategies and organizational competitiveness in the hotel industry: The role of learning and innovation as determinants of environmental success. Tourism Management, 46, 30-42.

Ghasemaghaei, M., Hassanein, K., \& Turel, O. (2017). Increasing firm agility through the use of data analytics: The role of fit. Decision Support Systems, 101, 95-105.

Golgeci, I., \& Ponomarov, S. Y. (2013). Does firm innovativeness enable effective responses to supply chain disruptions? An empirical study. Supply Chain Management: An International Journal, 18(6), 604-617.

Golinska-Dawson, P., Fertsch, M., \& Pawlewski, P. (2011). Production flow control in the automotive industry-quick scan approach. International Journal of Production Research, 49(14), 4335-4351.

Golinska-Dawson, P., Kosacka, M., Mierzwiak, R., \& Werner-Lewandowska, K. (2015). Grey decision making as a tool for the classification of the sustainability level of remanufacturing companies. Journal of Cleaner Production, 105, 28-40.

Grover, V., Chiang, R. H., Liang, T. P., \& Zhang, D. (2018). Creating strategic business value from big data analytics: A research framework. Journal of Management Information Systems, 35(2), 388-423.

Guide, V. D. R., Jr., \& Ketokivi, M. (2015). Notes from the editors: Redefining some methodological criteria for the journal. Journal of Operations Management, 37(1), v-viii.

Gupta, M., \& George, J. F. (2016). Toward the development of a big data analytics capability. Information and Management, 53(8), 1049-1064.

Hair, J. F., Black, W. C., Babin, B. J., Anderson, R. E., \& Tatham, R. L. (2006). Multivariate data analysis. Upper Saddle.

Hair, J. F. H., Hult, G. T. M., Ringle, C. M., \& Sarstedt, M. (2017). A primer on partial least squares structural equation modeling (PLS-SEM) (2nd ed.). Sage, USA.

Hair, J. F., Sarstedt, M., Ringle, C. M., \& Mena, J. A. (2012). An assessment of the use of partial least squares structural equation modeling in marketing research. Journal of the Academy of Marketing Science, 40(3), 414-433.

Harman, H. H. (1967). Modern factor analysis. University of Chicago Press.

Hart, S. L., \& Dowell, G. (2011). Invited editorial: A natural-resource-based view of the firm: Fifteen years after. Journal of Management, 37(5), 1464-1479.

Hassini, E., Roh, J. J., Hong, P., \& Park, Y. (2008). Organizational culture and supply chain strategy: A framework for effective information flows. Journal of Enterprise Information Management, 21(4), 361-376.

Hayes, A. F. (2013). Introduction to mediation, moderation, and conditional process analysis: A regressionbased approach. USA: Guilford.

Hayes, A. F. (2018). Partial, conditional, and moderated mediation: Quantification, inference, and interpretation. Communication Monographs, 85(1), 4-40.

Heckmann, I., Comes, T., \& Nickel, S. (2015). A critical review on supply chain risk-Definition, measure and modelling. Omega, 52, 119-132.

Helfat, C. E., \& Winter, S. G. (2011). Untangling dynamic and operational capabilities: Strategy for the (N) ever-changing world. Strategic Management Journal, 32(11), 1243-1250.

Henseler, J., Ringle, C. M., \& Sarstedt, M. (2015). A new criterion for assessing discriminant validity in variance-based structural equation modeling. Journal of the Academy of Marketing Science, 43(1), $115-135$.

Hosseini, S., \& Ivanov, D. (2019). A new resilience measure for supply networks with the ripple effect considerations: A Bayesian network approach. Annals of Operations Research. https://doi.org/10.1007/ s10479-019-03350-8

Ivanov, D. (2020). Predicting the impacts of epidemic outbreaks on global supply chains: A simulation-based analysis on the coronavirus outbreak (COVID-19/SARS-CoV-2) case. Transportation Research Part E: Logistics and Transportation Review, 136, 101922. 
Ivanov, D. (2020b). Viable supply chain model: Integrating agility, resilience and sustainability perspectives-lessons from and thinking beyond the COVID-19 pandemic. Annals of Operations Research. https://doi. org/10.1007/s10479-020-03640-6

Ivanov, D., Dolgui, A., \& Sokolov, B. (2019). The impact of digital technology and Industry 4.0 on the ripple effect and supply chain risk analytics. International Journal of Production Research, 57(3), 829-846.

Karimi, J., \& Walter, Z. (2015). The role of dynamic capabilities in responding to digital disruption: A factorbased study of the newspaper industry. Journal of Management Information Systems, 32(1), 39-81.

Kim, G., Shin, B., Kim, K. K., \& Lee, H. G. (2011). IT capabilities, process-oriented dynamic capabilities, and firm financial performance. Journal of the Association for Information Systems, 12(7), 487-517.

Kim, M., Song, J., \& Triche, J. (2015). Toward an integrated framework for innovation in service: A resourcebased view and dynamic capabilities approach. Information Systems Frontiers, 17(3), 533-546.

Kolinski, A., Dujak, D., \& Golinska-Dawson, P. (Eds.). (2020). Integration of Information Flow for Greening Supply Chain Management. Springer.

Konovalenko, I., \& Ludwig, A. (2019). Event processing in supply chain management-The status quo and research outlook. Computers in Industry, 105, 229-249.

Kwon, O., Lee, N., \& Shin, B. (2014). Data quality management, data usage experience and acquisition intention of big data analytics. International Journal of Information Management, 34(3), 387-394.

Lalmazloumian, M., Wong, K. Y., Govindan, K., \& Kannan, D. (2016). A robust optimization model for agile and build-to-order supply chain planning under uncertainties. Annals of Operations Research, 240(2), 435-470.

LaValle, S., Lesser, E., Shockley, R., Hopkins, M. S., \& Kruschwitz, N. (2011). Big data, analytics and the path from insights to value. MIT Sloan Management Review, 52(2), 21-32.

Lee, C., \& Hallak, R. (2018). Investigating the moderating role of education on a structural model of restaurant performance using multi-group PLS-SEM analysis. Journal of Business Research, 88, 298-305.

Lee, H. L. (2004). The triple-A supply chain. Harvard Business Review, 82(10), 102-113.

Li, Q., Zeng, B., \& Savachkin, A. (2013). Reliable facility location design under disruptions. Computers and Operations Research, 40(4), 901-909.

Liu, Y., Jiang, C., \& Zhao, H. (2019). Assessing product competitive advantages from the perspective of customers by mining user-generated content on social media. Decision Support Systems. https://doi.org/ 10.1016/j.dss.2019.113079

Liu, Y., Lee, Y., \& Chen, A. N. (2020). How IT wisdom affects firm performance: An empirical investigation of 15-year US panel data. Decision Support Systems. https://doi.org/10.1016/j.dss.2020.113300

Majdzik, P., Akielaszek-Witczak, A., Seybold, L., Stetter, R., \& Mrugalska, B. (2016). A fault-tolerant approach to the control of a battery assembly system. Control Engineering Practice, 55, 139-148.

Malhotra, N. K., Kim, S. S., \& Patil, A. (2006). Common method variance in IS research: A comparison of alternative approaches and a reanalysis of past research. Management Science, 52(12), 1865-1883.

Marucheck, A., Greis, N., Mena, C., \& Cai, L. (2011). Product safety and security in the global supply chain: Issues, challenges and research opportunities. Journal of Operations Management, 29(7-8), 707-720.

McAfee, A., Brynjolfsson, E., Davenport, T. H., Patil, D. J., \& Barton, D. (2012). Big data: The management revolution. Harvard Business Review, 90(10), 60-68.

McLaren, T. S., Head, M. M., Yuan, Y., \& Chan, Y. E. (2011). A multilevel model for measuring fit between a firm's competitive strategies and information systems capabilities. MIS Quarterly, 35(4), 909-929.

Miah, S. J., Vu, H. Q., Gammack, J., \& McGrath, M. (2017). A big data analytics method for tourist behaviour analysis. Information and Management, 54(6), 771-785.

Mikalef, P., Krogstie, J., Pappas, I. O., \& Pavlou, P. (2020). Exploring the relationship between big data analytics capability and competitive performance: The mediating roles of dynamic and operational capabilities. Information and Management. https://doi.org/10.1016/j.im.2019.05.004

Min, H. (2019). Blockchain technology for enhancing supply chain resilience. Business Horizons, 62(1), $35-45$.

Nguyen, W. P., \& Nof, S. Y. (2019). Collaborative response to disruption propagation (CRDP) in cyber-physical systems and complex networks. Decision Support Systems, 117, 1-13.

Oke, A., \& Gopalakrishnan, M. (2009). Managing disruptions in supply chains: A case study of a retail supply chain. International Journal of Production Economics, 118(1), 168-174.

O’Reilly, C. A., III., \& Tushman, M. L. (2013). Organizational ambidexterity: Past, present, and future. Academy of Management Perspectives, 27(4), 324-338.

Ortas, E., Moneva, J. M., Burritt, R., \& Tingey-Holyoak, J. (2014). Does sustainability investment provide adaptive resilience to ethical investors? Evidence from Spain. Journal of Business Ethics, 124(2), 297-309.

Patel, P. C., Azadegan, A., \& Ellram, L. M. (2013). The effects of strategic and structural supply chain orientation on operational and customer-focused performance. Decision Sciences, 44(4), 713-753. 
Pavlov, A., Ivanov, D., Pavlov, D., \& Slinko, A. (2019). Optimization of network redundancy and contingency planning in sustainable and resilient supply chain resource management under conditions of structural dynamics. Annals of Operations Research. https://doi.org/10.1007/s10479-019-03182-6

Pereira, J. V. (2009). The new supply chain's frontier: Information management. International Journal of Information Management, 29(5), 372-379.

Pettit, T. J., Croxton, K. L., \& Fiksel, J. (2019). The evolution of resilience in supply chain management: A retrospective on ensuring supply chain resilience. Journal of Business Logistics, 40(1), 56-65.

Pigni, F., Piccoli, G., \& Watson, R. (2016). Digital data streams: Creating value from the real-time flow of big data. California Management Review, 58(3), 5-25.

Podsakoff, P. M., MacKenzie, S. B., Lee, J. Y., \& Podsakoff, N. P. (2003). Common method biases in behavioral research: A critical review of the literature and recommended remedies. Journal of Applied Psychology, $88(5), 879$.

Ponomarov, S. Y., \& Holcomb, M. C. (2009). Understanding the concept of supply chain resilience. The International Journal of Logistics Management, 20(1), 124-143.

Preacher, K. J., \& Hayes, A. F. (2008). Asymptotic and resampling strategies for assessing and comparing indirect effects in multiple mediator models. Behavior Research Methods, 40(3), 879-891.

Saggi, M. K., \& Jain, S. (2018). A survey towards an integration of big data analytics to big insights for value-creation. Information Processing and Management, 54(5), 758-790.

Sande, J. B., \& Ghosh, M. (2018). Endogeneity in survey research. International Journal of Research in Marketing, 35(2), 185-204.

Schilke, O. (2014). On the contingent value of dynamic capabilities for competitive advantage: The nonlinear moderating effect of environmental dynamism. Strategic Management Journal, 35(2), 179-203.

Seddon, J. J., \& Currie, W. L. (2017). A model for unpacking big data analytics in high-frequency trading. Journal of Business Research, 70, 300-307.

Shamim, S., Zeng, J., Shariq, S. M., \& Khan, Z. (2019). Role of big data management in enhancing big data decision-making capability and quality among Chinese firms: A dynamic capabilities view. Information and Management. https://doi.org/10.1016/j.im.2018.12.003

Shao, B. B., Shi, Z. M., Choi, T. Y., \& Chae, S. (2018). A data-analytics approach to identifying hidden critical suppliers in supply networks: Development of nexus supplier index. Decision Support Systems, 114, 37-48.

Sheffi, Y., \& Rice, J. B., Jr. (2005). A supply chain view of the resilient enterprise. MIT Sloan Management Review, 47(1), 41-48.

Shi, X., \& Liao, Z. (2015). Inter-firm dependence, inter-firm trust, and operational performance: The mediating effect of e-business integration. Information and Management, 52(8), 943-950.

Shibin, K. T., Dubey, R., Gunasekaran, A., Hazen, B., Roubaud, D., Gupta, S., \& Foropon, C. (2020). Examining sustainable supply chain management of SMEs using resource based view and institutional theory. Annals of Operations Research, 290(1), 301-326.

Shorfuzzaman, M., Hossain, M. S., Nazir, A., Muhammad, G., \& Alamri, A. (2019). Harnessing the power of big data analytics in the cloud to support learning analytics in mobile learning environment. Computers in Human Behavior, 92, 578-588.

Simchi-Levi, D., Schmidt, W., \& Wei, Y. (2014). From superstorms to factory fires: Managing unpredictable supply chain disruptions. Harvard Business Review, 92(1-2), 96-101.

Sreedevi, R., \& Saranga, H. (2017). Uncertainty and supply chain risk: The moderating role of supply chain flexibility in risk mitigation. International Journal of Production Economics, 193, 332-342.

Srinivasan, R., \& Swink, M. (2018). An investigation of visibility and flexibility as complements to supply chain analytics: An organizational information processing theory perspective. Production and Operations Management, 27(10), 1849-1867.

Sun, L., Wang, Y., Hua, G., Cheng, T. C. E., \& Dong, J. (2020). Virgin or recycled? Optimal pricing of 3D printing platform and material suppliers in a closed-loop competitive circular supply chain. Resources, Conservation and Recycling, . https://doi.org/10.1016/j.resconrec.2020.105035

Sun, S., Cegielski, C. G., Jia, L., \& Hall, D. J. (2018). Understanding the factors affecting the organizational adoption of big data. Journal of Computer Information Systems, 58(3), 193-203.

Swamidass, P. M., \& Newell, W. T. (1987). Manufacturing strategy, environmental uncertainty and performance: A path analytic model. Management Science, 33(4), 509-524.

Syed, T. A., Blome, C., \& Papadopoulos, T. (2020). Resolving paradoxes in IT success through IT ambidexterity: The moderating role of uncertain environments. Information \&amp; Management. https://doi.org/ 10.1016/j.im.2020.103345

Tang, C. S. (2006). Robust strategies for mitigating supply chain disruptions. International Journal of Logistics: Research and Applications, 9(1), 33-45. 
Teece, D. J. (2007). Explicating dynamic capabilities: The nature and micro foundations of (sustainable) enterprise performance. Strategic Management Journal, 28(13), 1319-1350.

Teece, D. J. (2014). A dynamic capabilities-based entrepreneurial theory of the multinational enterprise. Journal of International Business Studies, 45(1), 8-37.

Teece, D., \& Leih, S. (2016). Uncertainty, innovation, and dynamic capabilities: An introduction. California Management Review, 58(4), 5-12.

Teece, D., Peteraf, M., \& Leih, S. (2016). Dynamic capabilities and organizational agility: Risk, uncertainty, and strategy in the innovation economy. California Management Review, 58(4), 13-35.

Teece, D., \& Pisano, G. (2003). The dynamic capabilities of firms. Handbook on Knowledge Management (pp. 195-213). Berlin, Heidelberg, Germany: Springer.

Teo, T. S., \& Pian, Y. (2003). A contingency perspective on Internet adoption and competitive advantage. European Journal of Information Systems, 12(2), 78-92.

Tirkolaee, E. B., Hadian, S., Weber, G. W., \& Mahdavi, I. (2020). A robust green traffic-based routing problem for perishable products distribution. Computational Intelligence, 36(1), 80-101.

Tiwari, S., Wee, H. M., \& Daryanto, Y. (2018). Big data analytics in supply chain management between 2010 and 2016: Insights to industries. Computers and Industrial Engineering, 115, 319-330.

Tomlin, B. (2006). On the value of mitigation and contingency strategies for managing supply chain disruption risks. Management Science, 52(5), 639-657.

Tönnissen, S., \& Teuteberg, F. (2020). Analysing the impact of blockchain-technology for operations and supply chain management: An explanatory model drawn from multiple case studies. International Journal of Information Management. https://doi.org/10.1016/j.ijinfomgt.2019.05.009

Villena, V. H., Lu, G., Gomez-Mejia, L. R., \& Revilla, E. (2018). Is top management team-supply chain manager interaction the missing link? An analysis of risk-bearing antecedents for supply chain managers. International Journal of Operations and Production Management, 38(8), 1640-1663.

Wamba, S. F., Dubey, R., Gunasekaran, A., \& Akter, S. (2020). The performance effects of big data analytics and supply chain ambidexterity: The moderating effect of environmental dynamism. International Journal of Production Economics. https://doi.org/10.1016/j.ijpe.2019.09.019

Wamba, S. F., Gunasekaran, A., Dubey, R., \& Ngai, E. W. (2018). Big data analytics in operations and supply chain management. Annals of Operations Research, 270(1-2), 1-4.

Wang, N., Hua, Y., Wu, G., Zhao, C., \& Wang, Y. (2019). Reverse transfer of innovation and subsidiary power: A moderated mediation model. Journal of Business Research, 103, 328-337.

Werner, S., Praxedes, M., \& Kim, H. G. (2007). The reporting of nonresponse analyses in survey research. Organizational Research Methods, 10(2), 287-295.

Winter, S. G. (2003). Understanding dynamic capabilities. Strategic Management Journal, 24(10), 991-995.

Xia, Y., Liu, B., Wang, S., \& Lai, K. K. (2000). A model for portfolio selection with order of expected returns. Computers and Operations Research, 27(5), 409-422.

$\mathrm{Xu}$, J., Zhuang, J., \& Liu, Z. (2016). Modelling and mitigating the effects of supply chain disruption in a defender-attacker game. Annals of Operations Research, 236(1), 255-270.

Xue, K., Li, Y., Zhen, X., \& Wang, W. (2018). Managing the supply disruption risk: Option contract or order commitment contract? Annals of Operations Research, 291, 985-1026.

Yayla, A. A., \& Hu, Q. (2012). The impact of IT-business strategic alignment on firm performance in a developing country setting: Exploring moderating roles of environmental uncertainty and strategic orientation. European Journal of Information Systems, 21(4), 373-387.

Yu, W., Jacobs, M. A., Chavez, R., \& Yang, J. (2019). Dynamism, disruption orientation, and resilience in the supply chain and the impacts on financial performance: A dynamic capabilities perspective. International Journal of Production Economics, 218, 352-362.

Publisher's Note Springer Nature remains neutral with regard to jurisdictional claims in published maps and institutional affiliations. 